\title{
Stipraus štormo „Feliksas“ padariniai Lietuvos jūriniame krante
}

\section{Darius Jarmalavičius,}

\section{Gintautas Žilinskas,}

Donatas Pupienis

Gamtos tyrimu centras, Akademijos g. 2, LT-08412 Vilnius

El.paštas: jarmalavicius@geo.lt; zilinskas@geo.lt; donatas.pupienis@vu.gf.lt
Jarmalavičius D., Žilinskas G., Pupienis D. Stipraus štormo „Feliksas“ padariniai Lietuvos jūriniame krante. Geologija. Geografija. 2015. T. 1(1). ISSN 2351-7549.

Ryškiausi kranto morfologijos pokyčiai fiksuojami prasiautus stipriems štormams bei uraganams, kai per trumpą laiką (keletą ar keliolika valandų) iš kranto išplaunami dideli smèlio kiekiai, paplūdimiai tampa siauri ir lèkšti, kopagūbrio jūriniame šlaite susiformuoja skardžiai. $2015 \mathrm{~m}$. sausio $11 \mathrm{~d}$. siautèjęs stiprus štormas „Feliksas", nors savo galingumu neprilygo didžiausiems XX a. uraganams, tačiau padaryti nuostoliai kai kuriems Lietuvos jūrinio kranto ruožams buvo reikšmingi. Remiantis natūrinių tyrimų duomenimis, įvertinti išplauto iš paplūdimio ir kopagūbrio bei viso kranto sąnašų kiekiai, nustatytos labiausiai pažeistos ir geriausiai stipraus štormo poveiki atlaikiusios kranto atkarpos. Per stiprų štormą „Feliksas" Lietuvos jūrinis krantas prarado apie $0,76 \mathrm{mln} . \mathrm{m}^{3}$ sąnašų: $0,39 \mathrm{mln} . \mathrm{m}^{3}$ iš žemyno kranto ir $0,37 \mathrm{~m}^{3} \mathrm{mln}$. iš Kuršių nerijos kranto. Didžiąją nuoplovos dali $\left(631000 \mathrm{~m}^{3}\right.$, arba net $\left.80 \%\right)$ sudare paplūdimio sąnašos, o kopagūbris nukentèjo sąlyginai nedaug $\left(127000 \mathrm{~m}^{3}\right.$; arba tik $\left.20 \%\right)$.

Raktažodžiai: štormas „Feliksas“, kranto, paplūdimio, kopagūbrio arda, Baltijos jūra

\section{IVADAS}

Ekstremaliomis hidrometeorologinėmis sąlygomis vykstančių krantinių procesų tyrimai yra ypač svarbūs ne tik plečiant teorines krantotyros žinias, bet ir tobulinant krantosaugos būdus, užtikrinant hidrotechninių statinių saugumą bei prognozuojant kranto raidą. Deja, tiesioginiai instrumentiniai hidrodinaminių ir litodinaminių procesų tyrimai kranto zonoje dèl ypač sudètingų hidrometeorologinių sąlygų, stiprių štormų (vẻjo greitis siekia 28,4-32,7 m/s; Krapivin et al., 2015) ir uraganinio stiprumo vejjų (vejjo greitis didesnis nei $32,7 \mathrm{~m} / \mathrm{s}$; Krapivin et al., 2015) beveik neatliekami (išimtį dažniausiai sudaro vandens lygio bei vejo greičio ir krypties matavimai). Todèl apie šių procesų intensyvumą dažniausiai sprendžiama ịvertinus stiprių štormų (toliau - štormų) bei uraganinio stiprumo vejų (toliau - uraganų) padarinių pobūdị bei apimtis.

Pirmieji duomenys apie uragano poveiki visam Lietuvos jūriniam krantui paskelbti J. Shuiskio straipsnyje (1969). Šie tyrimai buvo atlikti po smarkiausio XX a. uragano, siautusio $1967 \mathrm{~m}$. spalio $18 \mathrm{~d}$. Jo poveikis krantui buvo vertintas remiantis išplautų sąnašų kiekiu iš vieno tiesinio metro $-\mathrm{m}^{3} / \mathrm{m}$ (Shuiskyi, 1969). Štormų bei uraganų, kurie siaute 1983 m. žiemą, 1999 m. gruodžio pradžioje ir $2005 \mathrm{~m}$. sausio mèn., poveikio Lietuvos krantams vertinimą galima rasti ankstesniuose darbuose (Kirlys, 1990; Žilinskas ir kt., 2000; 2005). Kituose tyrimuose buvo vertinamas štormų ir uraganų poveikis tik kai kuriems objektams: Šventosios uostui (Šimoliūnas, 1933), Klaipèdos uostui (Korobova, 1969), Palangos rekreacinei zonai (Žilinskas ir kt., 1994) arba aptariama vejjo 
greičio dinamika buvusių XX a. (iki 8 deš.) štormų ir uraganų metu (Žaromskis, 1982).

Straipsnio tikslas - ivvertinti Lietuvos jūrinio kranto sąnašu pokyčius po $2015 \mathrm{~m}$. sausio $11 \mathrm{~d}$. prasiautusio štormo „Feliksas“.

\section{METEOROLOGINĖ SITUACIJA IR METODIKA}

$2015 \mathrm{~m}$. sausio $9 \mathrm{~d}$. Atlanto vandenyne pradejęs formuotis ciklonas, kuriam vèliau buvo suteiktas „Felikso“ vardas, judedamas link Skandinavijos išsiskaide $\mathfrak{i}$ kelis labai aktyvius ciklonus. Vienas jų sausio $11 \mathrm{~d}$. nakti pasiekè Lietuvos krantus. Klaipedos meteorologijos stoties duomenimis, VPV vëjų vidutinis greitis sieké $15 \mathrm{~m} / \mathrm{s}$, o gūsiai sustiprèdavo iki $28 \mathrm{~m} / \mathrm{s}$. Stipresni vejjai buvo užregistruoti Klaipėdos uosto akvatorijoje. Čia fiksuotas $25 \mathrm{~m} / \mathrm{s}$ vidutinis vejjo greitis, o gūsiai pasiekdavo $32,5 \mathrm{~m} / \mathrm{s}$. Gūsingas vèjas išsilaikè beveik visą dieną. Pažymètina, kad krantas pasitiko ši štormą jau gerokai „nuvargęs“, mat audros ji alino nuo $2014 \mathrm{~m}$. gruodžio vidurio. Antai gruodžio 13 d. praslinkusị cikloną lydèjo PV vèjo gùsiai, siekiantys iki $20 \mathrm{~m} / \mathrm{s}$. $2015 \mathrm{~m}$. sausio 2-3 d. praslinko dar vienas gilus ciklonas, kurio metu $\mathrm{V}$ krypčių vèjai vidutiniškai pūtė $13 \mathrm{~m} / \mathrm{s}$ greičiu, o jo gūsiai sustiprèdavo iki $22 \mathrm{~m} / \mathrm{s}$. Klaipèdos uosto akvatorijoje buvo užfiksuoti $26 \mathrm{~m} / \mathrm{s}$ vèjo gūsiai. Taigi, nors „Feliksas“ ir nepasižyméjo ypatingu nuožmumu, tačiau užgriuvo jūros krantą, jau nukentèjusį nuo ankstesnių audrų.

„Felikso“ padarinių Lietuvos jūriniams krantams tyrimai buvo atliekami $2015 \mathrm{~m}$. sausio 2227 d., štormui aprimus ir nukritus jūros lygiui. Tyrimų metu skersinių kranto profilių niveliacija (elektroniniu tacheometru - TOPCON GTS 229) buvo atliekama stacionarinių matavimo postų, ịrengtų visame Lietuvos pajūryje, vietose (1 pav.).

Šie matavimų duomenys buvo palyginti su matavimų, atliktų $2014 \mathrm{~m}$. vasaros pradžioje tuose pačiose profiliuose, duomenimis. Gauti skirtumai apytikriai parode išplautų ar akumuliuotų sąnašų kiekius ( $\mathrm{m}^{3}$ iš 1 kranto metro) iš apsauginio paplūdimio kopagūbrio (toliau - kopagūbrio), paplūdimio bei viso kranto. Sąnašų pokyčiai išilgai kranto apskaičiuoti pagal formulę (Eberhards, 2006):

$$
V=\left(Q_{i}+Q_{i+1}\right) L_{i} / 2 \text {; }
$$

$V$ - sąnašų biudžetas kranto ruože, $Q$ - sąnašų biudžetas skersiniame kranto profilyje $\left(\mathrm{m}^{3} / \mathrm{m}\right)$, $i$ - skersinio profilio numeris, $L$ - atstumas tarp matavimo profilių.

Pažymètina, kad stiprių štormų ir uraganų metu ịvykę pokyčiai ženkliai viršija tiek vidutinius daugiamečius, tiek ir metinius pokyčius (Eberhards, 2003; Žilinskas ir kt., 2005; Castelle et al., 2007; Corbella, Stretch, 2012). Taigi, pokyčiai, ịvykę nuo paskutinio matavimo $2014 \mathrm{~m}$. vasaros pradžioje iki „Felikso“, laikytini nereikšmingais, palyginti juos su pokyčiais, vykusiais „Felikso“ metu. Todèl atliktų tyrimų rezultatai santykinai atspindi analizuojamo štormo padarinius. Panaši tyrimų metodika taikoma ir kitose šalyse (Gorman et al., 1998; Eberhards et al., 2006; Castelle et al., 2007; Keijsers et al., 2014).

Nors tyrimų metu buvo fiksuojami (šiame darbe pateikiami) ir kranto linijos bei kopagūbrio papédès ir viršūnès linijiniai $(\mathrm{m})$ pokyčiai, tačiau štormo padarinių vertinimo pagrindiniu geoindikatoriumi pasirinktas išplautų ar akumuliuotų sąnašų kiekis viename kranto metre $\left(\mathrm{m}^{3} / \mathrm{m}\right)$. Kadangi šis rodiklis atspindi kranto būklès pokyčius ir tose kranto atkarpose, kur po štormo kranto linijos ar kopagūbrio viršūnès padètis erdveje išliko stabili, bet pakito sąnašų kiekis pažemejjus paplūdimiams bei bangoms apardžius kopagūbrio papėdę ar / ir vakarinị šlaitą. Analizuojant tyrimų metu surinktus duomenis Lietuvos jūriniame krante, buvo išskirti kranto ruožai, kuriuose per štormą ịvykusių pokyčių tendencijos bei apimtys buvo sąlyginai panašios.

\section{ŠTORMO POVEIKIS ŽEMYNO KRANTUI}

Per štormą maždaug $32,5 \mathrm{~km}(84,4 \%)$ žemyno kranto buvo nuardyta, o apie $6,0 \mathrm{~km}(15,6 \%)$ sąnašų kiekis nepakito ar net pasipildè. Iš viso žemyno kranto buvo išplauta maždaug $366000 \mathrm{~m}^{3}$ smèlio (arba $\left.9,7 \mathrm{~m}^{3} / \mathrm{m}\right): 316000 \mathrm{~m}^{3}\left(8,4 \mathrm{~m}^{3} / \mathrm{m}\right)$ iš paplūdimio ir $50000 \mathrm{~m}^{3}\left(1,3 \mathrm{~m}^{3} / \mathrm{m}\right)$ iš kopagūbrio. Kranto linija atsitraukè vidutiniškai $8,1 \mathrm{~m}$. Kranto linijos padèties ir kranto sąnašų kiekio kaita pateikta 2 ir 3 paveiksluose.

Kaip matyti 2 ir 3 pav., ardos mastai skirtinguose kranto ruožuose ženkliai skyrèsi. Daugiausia smèlio žemyno krante buvo nuplauta ties Rąž̀s upeliu (maždaug $16 \mathrm{~km}$ nuo sienos su Latvija), kur kranto linija atsitraukus $29 \mathrm{~m}$, iš kranto buvo išplauta net $46,8 \mathrm{~m}^{3} / \mathrm{m}$ smèlio. 


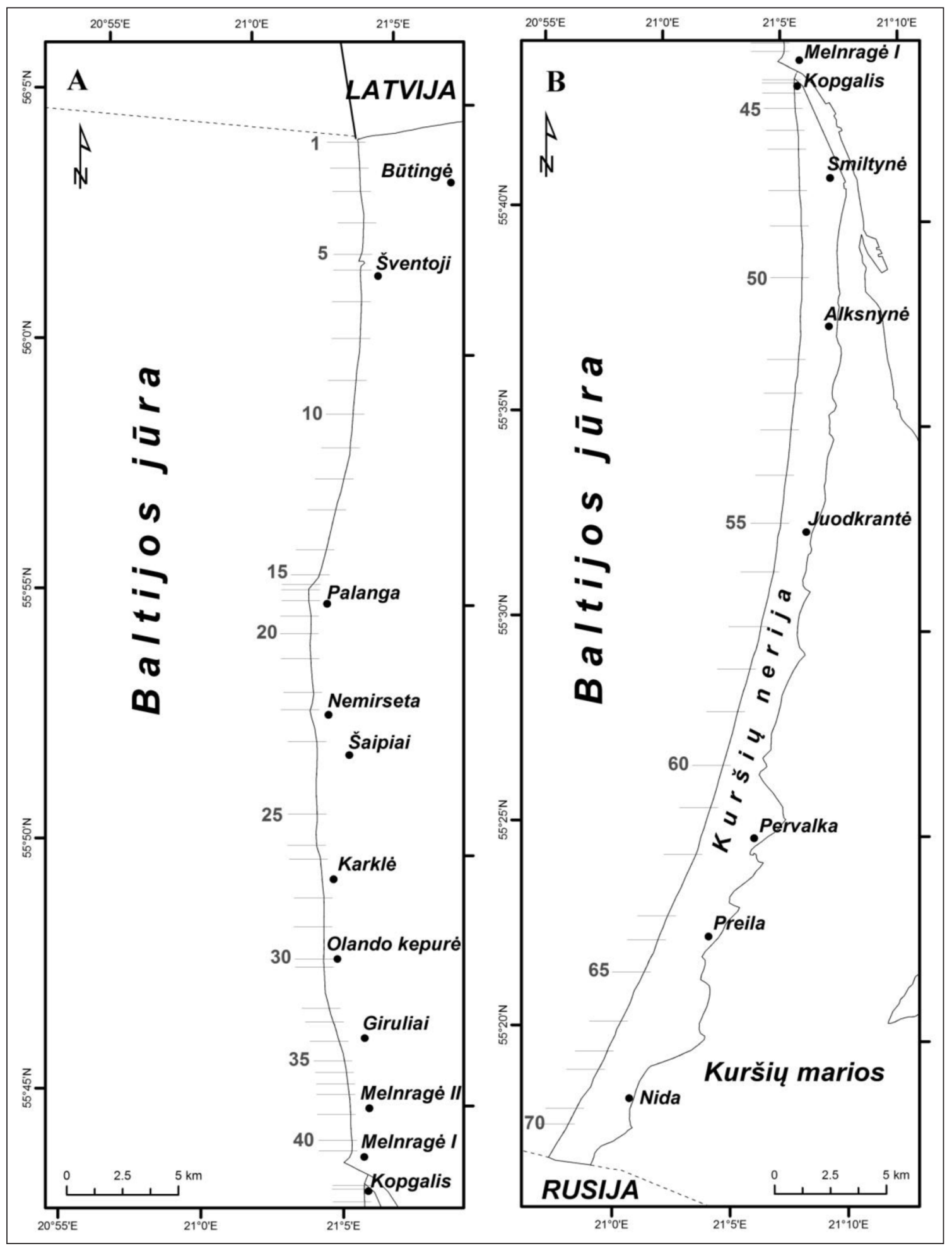

1 pav. Tyrimų rajonas: A - žemyno krantas, B - Kuršių nerija. 1-70 - matavimo profilių vietos

Fig. 1. Location map: $A$ is mainland coast, B is Curonian Spit. 1-70 are cross-shore levelling sites

Tačiau ši intensyvios ardos kranto atkarpa labai trumpa (apie $100 \mathrm{~m}$ ), be to, net keletą metų prieš ši štormą čia vyko gana intensyvi smèlio akumuliacija, todèl netekus ir santykinai daug smèlio praradimas čia nesukèlè problemų. Visas smèlio kie- kis šioje atkarpoje buvo išplautas iš paplūdimio, o kopagūbris išliko nepažeistas.

Kranto ruože tarp Birutès kalno $(18 \mathrm{~km})$ ir Nemirsetos kyšulio $(21 \mathrm{~km})$ siauresni bei žemesni paplūdimiai nepajège apsaugoti nuo išplovimų ir 


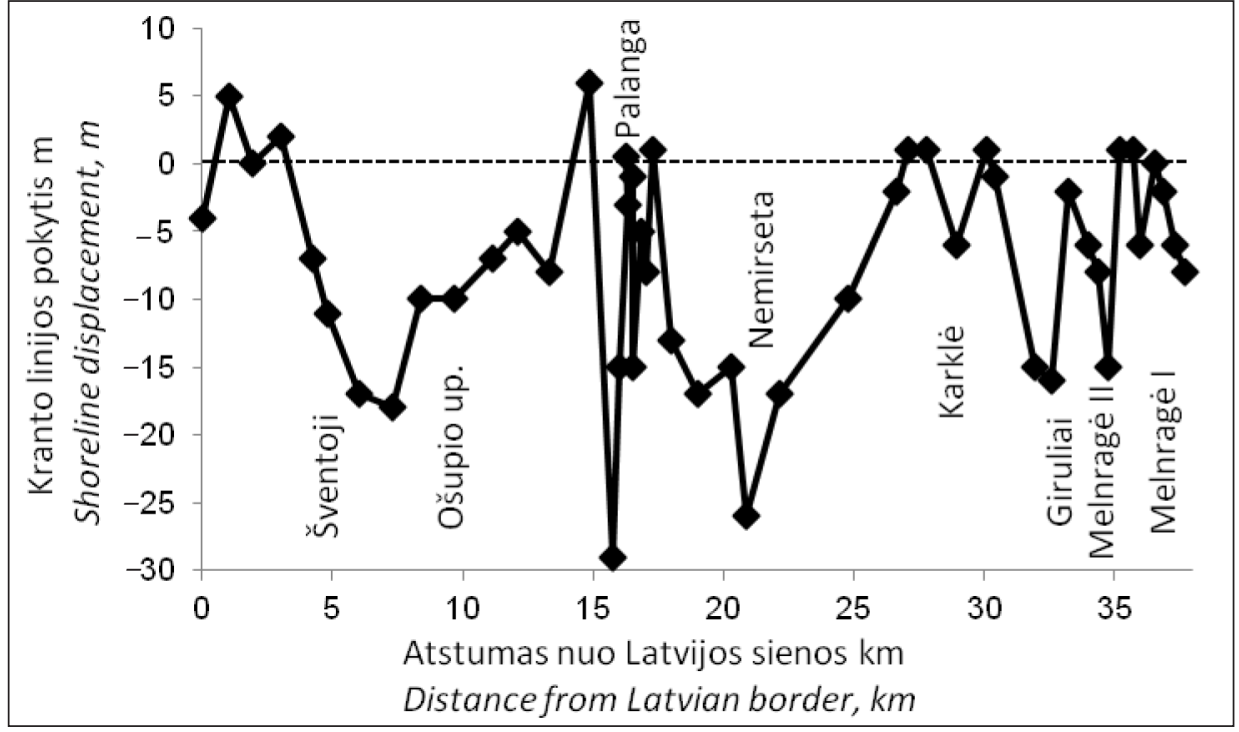

2 pav. Kranto linijos padèties pokytis žemyno krante po štormo

Fig. 2. Displacement of shoreline position in the mainland coast after the storm kopagūbrio. Nors kranto arda čia buvo mažesnè (vidutiniškai $20,4 \mathrm{~m}^{3} / \mathrm{m}$ ), tačiau krantas patyrè sąlyginai didesnių nuostolių. Iš kopagūbrio, jo papèdei atsitraukus 2-3 m, buvo išplauta apie $4,4 \mathrm{~m}^{3} / \mathrm{m}$ smèlio. Tai didžiausios kopagūbrio ardos apimtys visame žemyno krante. Nemaži sąnašų kiekiai čia buvo išplauti ir iš paplūdimio - net $16,0 \mathrm{~m}^{3} / \mathrm{m}$ smèlio.

Dar mažesnè kopagūbrio arda $\left(3,6 \mathrm{~m}^{3} / \mathrm{m}\right)$ užfiksuota $1 \mathrm{~km}$ ilgio kranto ruože nuo valstybinès sienos su Latvija iki Būtingès naftos terminalo vamzdyno trasos. Tačiau čia (kadangi kopagūbris yra ženkliai žemesnis ir siauresnis nei anksčiau minètame ruože) panašus smèlio kiekio praradimas lèmé, kad kopagūbrio papèdè atsitraukè vidutiniškai net $4 \mathrm{~m}$. Dèl mažų smèlio atsargų, sukauptų krante, iki štormo stipriai pablogejo kranto būklè ir pietinèje I-os Melnragès (300 m ilgio atkarpa nuo Klaipedos uosto molo ị šiaurę) kranto atkarpoje. Čia taip pat esant nedideliems smèlio kiekiams kopagūbryje, praradus santykinai nedaug smèlio $\left(3,3-3,8 \mathrm{~m}^{3} / \mathrm{m}\right)$, kopagūbrio papèdè atsitraukè 2,0-3,5 m. Pakankamai ženkliai šioje kranto atkarpoje nukentejo ir paplūdimiai, iš kurių buvo išplauta $10,7-29,5 \mathrm{~m}^{3} / \mathrm{m}$ smèlio.

Labiau nei kopagūbris nukentèjo paplūdimiai ir kranto ruože tarp Monciškès $(7,5 \mathrm{~km})$ ir Kunigiškès $(12 \mathrm{~km})$ gyvenviečių. Čia iš paplūdimio buvo išplauta $4,5-18,6 \mathrm{~m}^{3} / \mathrm{m}$ smèlio, o kopagūbrio papèdei atsitraukus $0,5-2,5 \mathrm{~m}$ iš jo buvo išplauta tik $0,5-2,5 \mathrm{~m}^{3} / \mathrm{m}$ smèlio. Iš viso šioje kranto atkarpoje krantas neteko nuo 5,0 iki $21,0 \mathrm{~m}^{3} / \mathrm{m}$ smèlio. Dar mažiau kopagūbris nukentèjo kranto ruože nuo Šventosios moterų paplūdimio pietinès ribos

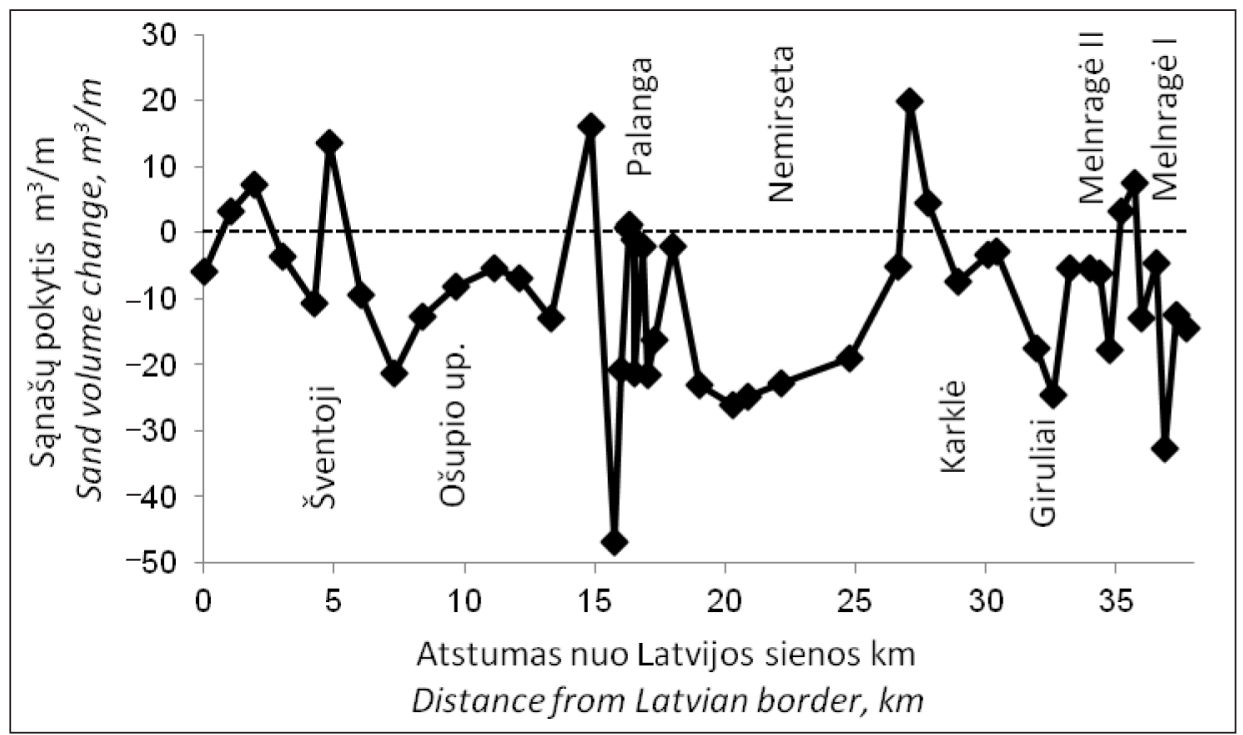

3 pav. Sąnašų kiekio pokytis žemyno krante po štormo

Fig. 3. Changes of sand volume in the mainland coast after the storm 
$(6,0 \mathrm{~km})$ iki Monciškių $(7,5 \mathrm{~km})$ - jame vidutinis išplauto iš kopagūbrio smèlio kiekis sudare tik $0,1 \mathrm{~m}^{3} / \mathrm{m}$, tačiau ženkliai $\left(14,0 \mathrm{~m}^{3} / \mathrm{m}\right)$ sumažèjo paplūdimio smèlio atsargos.

Šaipių (25-27 km) bei Olando Kepurès (29$30,5 \mathrm{~km}$ ) moreninių skardžių ruožuose po štormo skardžių viršūnių bei papèdžių padètis erdvejje beveik nepasikeite, o prie jų prisišlieję paplūdimiai prarado $2,0-5,2 \mathrm{~m}^{3} / \mathrm{m}$ sąnašų. Nedidelius išplovimus patyre ir kranto ruožas, esantis tarp pietinès Būtingès geomorfologinio draustinio ribos $(2 \mathrm{~km})$ ir Šventosios upès žiočių $(4,5 \mathrm{~km})$, kuriame kopagūbris per štormą neteko apie $1,8 \mathrm{~m}^{3} / \mathrm{m}$, o paplūdimys $-1,2 \mathrm{~m}^{3} / \mathrm{m}$ smèlio.

Pažymètina, kad kelios žemyno kranto atkarpos išliko stabilios ar net pasipilde sąnašomis. Pirmiausiai reiketų paminèti kranto ruožą tarp Šventosios upès žiočių $(4,5 \mathrm{~km})$ ir Šventosios rekreacinès zonos moterų paplūdimio pietinès ribos $(6 \mathrm{~km})$, nors paplūdimys čia neteko apie $0,8 \mathrm{~m}^{3} / \mathrm{m}$ smèlio, tačiau kopagūbris pasipildè beveik $4,8 \mathrm{~m}^{3} / \mathrm{m}$. Šiame ruože bendras kranto smèlio biudžetas po štormo buvo teigiamas - jame vidutiniškai akumuliuota $4,0 \mathrm{~m}^{3} / \mathrm{m}$ smèlio. Sąnašų kiekis padidejo ir kranto atkarpoje tarp Būtingès naftos terminalo trasos $(1 \mathrm{~km})$ ir „Energetiko“ poilsio komplekso $(3,5 \mathrm{~km})$. Ši kranto atkarpa nepasižymi didelèmis smèlio atsargomis nei paplūdimyje, nei kopagūbryje. Be to, dar prieš keletą metų joje vyravo kranto ardos tendencijos (Kriaučiūnienè ir kt., 2013). Per šį štormą ji nenukentejjo, o vietomis net pasipildè vidutiniškai $3,2-7,3 \mathrm{~m}^{3} / \mathrm{m}$ smèlio. Kita panaši kranto atkarpa, nepasižyminti stabilumu, tačiau puikiai atlaikiusi štormą, yra abipus Rykinès upelio (27-28 km).
Čia vietomis krantas smèliu ir gargždu pasipilde net iki $20,0 \mathrm{~m}^{3} / \mathrm{m}$. Kranto sąnašu atsargos po štormo padidejo ir kranto ruože tarp I-os ir II-os Melnragès (35-36,5 km); čia krantas pasipildè vidutiniškai $3,3-7,7 \mathrm{~m}^{3} / \mathrm{m}$ smèlio.

\section{ŠTORMO POVEIKIS KURŠIŲ NERIJOS KRANTUI}

Štormo metu nukentejjo iš viso apie $38,5 \mathrm{~km}$ (76 \%) ilgio Lietuvai priklausančio (bendras ilgis $51 \mathrm{~km}$ ) Kuršių nerijos jūrinio kranto, o $12,5 \mathrm{~km}$ (24\%) kranto nebuvo pažeista ar net pasipildè smèlio sąnašomis. Iš viso Lietuvai priklausančio Kuršių nerijos jūros kranto buvo išplauta apie $392000 \mathrm{~m}^{3}$ smélio (vidutiniškai $7,7 \mathrm{~m}^{3} / \mathrm{m}$ ): $315000 \mathrm{~m}^{3}\left(6,2 \mathrm{~m}^{3} / \mathrm{m}\right)$ iš paplūdimio ir $77000 \mathrm{~m}^{3}$ $\left(1,5 \mathrm{~m}^{3} / \mathrm{m}\right)$ iš kopagūbrio. Kranto linija atsitrauke i sausumą vidutiniškai 7,6 m. Kaip ir žemyno krante, taip ir Kuršių nerijoje, skirtinguose kranto ruožuose kranto linijos padèties ir kranto sąnašu kiekio pokyčiai buvo skirtingi (4 ir 5 pav.).

Didžiausius nuostolius „tradiciškai“, kaip ir po uraganų „Anatolijus" bei „Ervinas“ (Žilinskas ir kt., 2000, 2005), patyre trumpa (apie $200 \mathrm{~m}$ ilgio) Kopgalio kranto atkarpa, besiliečianti su pietiniu Klaipedos uosto molu. Čia, kranto linijai atsitraukus apie $30 \mathrm{~m}$, iš kranto buvo išplauta maždaug $51,0 \mathrm{~m}^{3} / \mathrm{m}$ smèlio. Taip pat šioje kranto atkarpoje užfiksuoti ir didžiausi smèlio išplovimai iš kopagūbrio $\left(26,0 \mathrm{~m}^{3} / \mathrm{m}\right)$; vakariniame kopagūbrio šlaite susiformavę skardžiai siekè $4,5 \mathrm{~m}$ aukštị. Reikètų prisiminti, kad prieš porą metų $3000 \mathrm{~m}^{3}$ smèlio, iškasto vykdant delfinariumo baseinų rekonstrukciją,

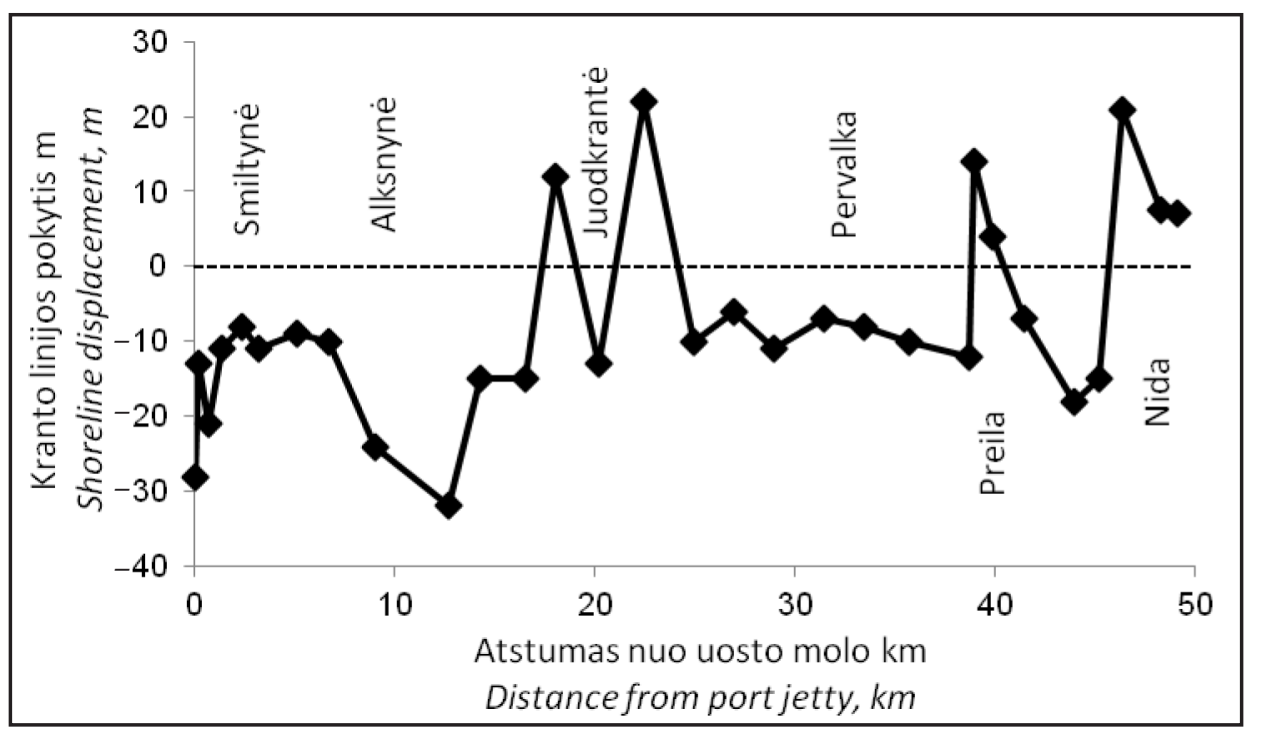

4 pav. Kranto linijos padèties pokytis Kuršiu nerijoje po štormo

Fig. 4. Displacement of shoreline position in the Curonian Spit coast after the storm 


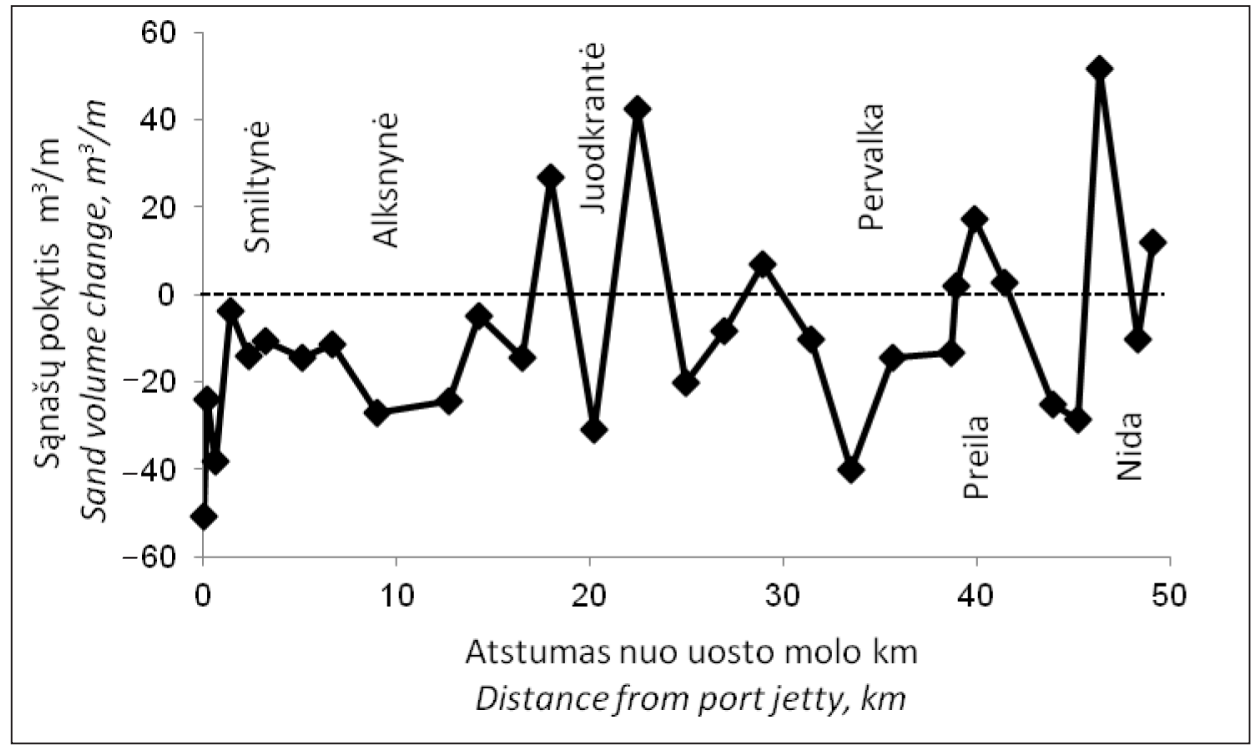

5 pav. Kranto sąnašų kiekio pokytis Kuršių nerijoje po štormo

Fig. 5. Changes of sand volume in the Curonian Spit coast after the storm

buvo supilta šios vietos kopagūbrio papèdèje. Taigi, nors ir dideli kiekiai buvo nuplauti, tačiau jie sudare tik apie $50 \%$ čia išpilto smèlio.

Nuo Klaipeddos uosto pietinio molo štormo apardytas kranto ruožas tęsiasi beveik $18 \mathrm{~km}$. Tačiau nuplauto iš kranto smèlio kiekis (vid. 13,5 m³ $/ \mathrm{m}$ ) joje ženkliai mažesnis nei anksčiau minètoje (200 m ilgio) atkarpèlèje. Šiame ruože išsiskiria ir kranto atkarpa tarp 8 ir $13 \mathrm{~km}$, kur, kranto linijai atsitraukus apie $25 \mathrm{~m}$, išplauto smèlio kiekiai (vid. $25,8 \mathrm{~m}^{3} / \mathrm{m}$ ) buvo beveik dvigubai didesni nei gretimose tiek šiauriau, tiek piečiau jos esančiose atkarpose. Taip pat pažymètina, kad pagrindine smėlio mase šioje atkarpoje išplauta iš paplūdimio (nuo $24,5 \mathrm{iki} 27,0 \mathrm{~m}^{3} / \mathrm{m}$ ), kopagūbris nedaug tenukentėjo $\left(0,2-0,5 \mathrm{~m}^{3} / \mathrm{m}\right)$, o atskirose atkarpose ir visai nebuvo pažeistas.

Didelių nuostolių patyrè ir apie $1 \mathrm{~km}$ ilgio, í šiaurę nuo Pervalkos gelbejjimo posto esanti, kranto atkarpa Čia, nors kranto linijos padetis erdvèje praktiškai nepakito, tačiau paplūdimys neteko vidutiniškai $22,0 \mathrm{~m}^{3} / \mathrm{m}$ smèlio, o kopagūbriui praradus vidutiniškai $18,0 \mathrm{~m}^{3} / \mathrm{m}$ smèlio atsivèrè net iki $6,5 \mathrm{~m}$ aukščio skardžiai. Bendras išplauto smèlio kiekis šiame ruože sieke $40,0 \mathrm{~m}^{3} / \mathrm{m}$. Ispūdingi (iki 5,6-5,8 m aukščio) skardžiai vakariniame kopagūbrio šlaite susiformavo ir pietinèje (apie $0,4 \mathrm{~km}$ ilgio) Nidos rekreacinès zonos dalyje.

Ne visi kranto ruožai patyrė nuostolių. Kranto atkarpose ties pietine Juodkrante, pietine Preila, šiaurinejje Nidos dalyje ir pasienyje su Kaliningrado sritimi bei keliose trumpesnèse kranto atkarpé- lèse krantas išliko stabilus, o kai kur net pasipildè smèlio atsargomis. Didžiausias kranto linijos padèties pasislinkimas ị jūrą $(22 \mathrm{~m})$ užfiksuotas piečiau Juodkrantės. Didžiausia smėlio akumuliacija $\left(52,0 \mathrm{~m}^{3} / \mathrm{m}\right)$ užfiksuota centrinèje Nidos rekreacinès zonos dalyje. Smèlio akumuliacija $\left(42,3 \mathrm{~m}^{3} / \mathrm{m}\right)$ krante užfiksuota ir ties pietine Juodkrante bei piečiau Preilos $\left(17,0 \mathrm{~m}^{3} / \mathrm{m}\right)$.

\section{DISKUSIJA}

Palyginus štormų bei uraganų, siautusių per pastaruosius 50 metų, poveiki Lietuvos jūrinio kranto būklei, galima teigti, kad štormas „Feliksas“ užima trečią vietą pagal išplautų iš Lietuvos jūrinio kranto sąnašų kieki (lentelè). Siekiant nustatyti, kaip vystèsi Lietuvos jūrinis krantas nuo didžiausius nuostolius atnešusio uragano „Anatolijaus“ iki šių dienų, buvo atlikta atskirų kranto ruožų pokyčių analizè. Pažymètina, kad po šio uragano jau praèjo du intensyvios kranto ardos (ekstremaliu hidrometeorologinių sąlygų) ir regeneracijos (santykinai ramių orų laikotarpio) ciklai („Anatolijaus“ - „Ervino“ ir „Ervino“ - „Felikso“). Tai leidžia pakankamai reprezentatyviai vertinti pastarųjų 16 metų kranto būklę.

Pažymètina, kad kranto regeneracijos laikotarpiu smèlio apykaita vyksta ne tik tarp jūros ir kranto, bet ir išilgai jo. Todèl vienos kranto atkarpos labai greitai atstato per štormus prarastą smèlio kieki, o kitos jo neatstato ir per kelerius metus. Tai lemia ne tik atskirų štormų savybès, bet ir kranto bei priekrantès morfologijos ypatumai, geologinè 
Lentelè. Sąnašų pokyčiai $\left(\mathrm{m}^{3} / \mathrm{m}\right)$ Lietuvos jūriniame krante po štormų ir uraganų

Table. Dynamics of sand volume $\left(\mathrm{m}^{3} / \mathrm{m}\right)$ in the Lithuania coast during storms and hurricanes

\begin{tabular}{c|c|cc}
\hline Data / Date & $\begin{array}{c}\text { Žemyno krantas } \\
\text { Mainland coast }\end{array}$ & $\begin{array}{c}\text { Kuršių nerija } \\
\text { Curonian spit }\end{array}$ & $\begin{array}{c}\text { Iš viso } \\
\text { Total }\end{array}$ \\
\hline 19671018 (Shuiskyi, 1969) & $-0,60 \mathrm{mln}$. & $-0,84 \mathrm{mln}$. & $-1,44 \mathrm{mln}$. \\
\hline $19830118-19$ (Kirlys, 1990) & - & $-0,77 \mathrm{mln}$. & - \\
\hline 19991204 (Žilinskas ir kt., 2000) & $-2,00 \mathrm{mln}$. & $-1,94 \mathrm{mln}$. & $-3,94 \mathrm{mln}$. \\
\hline $2005018-9$ (Žilinskas ir kt., 2005) & $-0,42 \mathrm{mln}$. & $+0,14 \mathrm{mln}$. & $-0,27 \mathrm{mln}$. \\
\hline 2015 01 11 & $-0,39 \mathrm{mln}$. & $-0,37 \mathrm{mln}$. & $-0,76 \mathrm{mln}$. \\
\hline
\end{tabular}

sandara, smèlio kiekis bei sudètis, hidrotechninių statiniu poveikis ir kt.

Vertinant Lietuvos jūrinio kranto būklès kaitos tendencijas per pastaruosius 16 metu nustatyta, kad degraduojantiems žemyno kranto ruožams priskirtinos kranto atkarpos tarp sienos su Latvija ir Būtingès naftos terminalo vamzdyno trasos, morenos skardžių prie Šaipių ir ties Olando Kepure bei I-os Melnragès pietinè dalis. Būtent šiose atkarpose kranto būklè $2015 \mathrm{~m}$. yra blogesnè nei buvo po uraganų „Anatolijus“ ir „Ervinas“. Pažymètina, kad kranto degradacijos procesus ties siena su Latvija (6 pav.), prie Šaipių ir ties Olando Kepure

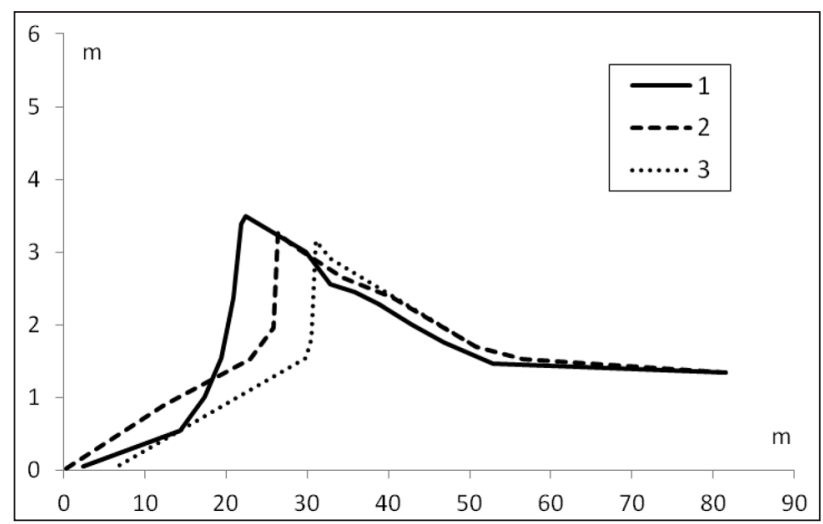

6 pav. Kranto profilis ties valstybine siena su Latvija po uraganų „Anatolijus“ (1), „Ervinas“ (2) ir štormo „Feliksas“ (3)

Fig. 6. Cross-shore profile near the Lithuanian-Latvian border after hurricanes Anatolij (1), Ervin (2), and storm Felix (3)

lemia gamtiniai veiksniai, o kranto ardą pietinèje I-os Melnragès puseje lemia gamtiniai veiksniai ir antropogeninès veiklos: iplaukos kanalo gilinimo darbai (Žilinskas, 1998) ir molų pailginimas (Jarmalavičius ir kt., 2012; Pupienis ir kt., 2013). Tą patvirtina ir tas faktas, kad uraganai „Anatolijus“ ir „Ervinas“ dèl čia vyravusių akumuliacijos procesų (7 pav.)

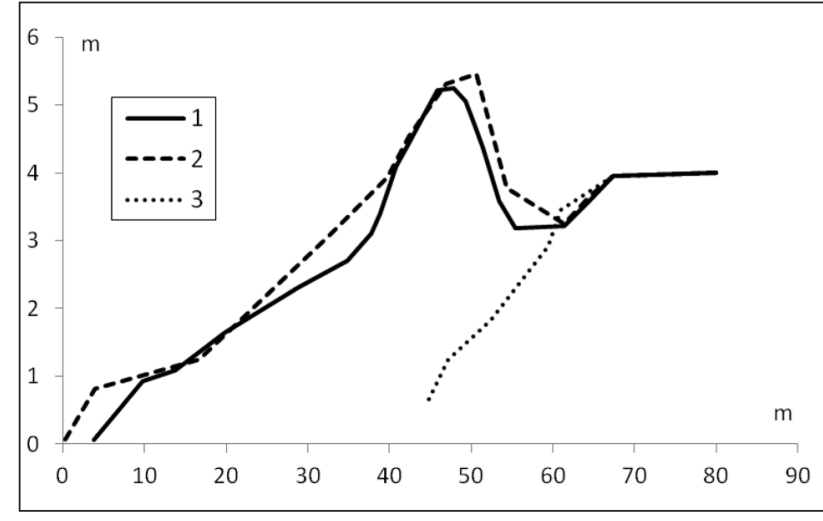

7 pav. Kranto profilis ties I-a Melnrage po uraganu „Anatolijus“ (1), „Ervinas“ (2) ir štormo „Feliksas“ (3)

Fig. 7. Cross-shore profile near Melnragè I after hurricanes Anatolij (1), Ervin (2), and storm Felix (3)

didesnès žalos nepadarè (Žilinskas ir kt., 2000, 2005). $2002 \mathrm{~m}$. baigus molų bei ịplaukos kanalo rekonstrukcijos darbus, šioje vietoje prasidejusi kranto arda kasmet igauna vis didesnius mastus. Antra vertus, išplautas iš šios atkarpos smèlis, pernešamas bangų ir plūsmo srauto ị šiaurę, ėmé kauptis kranto ruože tarp I-os ir II-os Melnragès (Jarmalavičius ir kt., 2012; Pupienis ir kt., 2013). Šiame kranto ruože pastaruoju metu fiksuojama sąnašų akumuliacija.

Atskirai reikètų apžvelgti Palangos rekreacinès zonos kranto ruožo tarp Rąžès upelio ir Birutès kalno pokyčius (8 ir 9 pav.), kadangi šiame ruože 2006, 2008 ir 2011-2012 m. buvo papildyta paplūdimio sąnašų (Žilinskas ir kt., 2010; Pupienis ir kt., 2014). Kaip jau buvo minèta, didžiausi smèlio kiekiai štormo metu buvo išplauti iš paplūdimio ties Rąžès upeliu. Link Palangos tilto esančioje atkarpoje ardos mastai buvo nedideli, o prie tilto krantas beveik visai nebuvo pažeistas. Kranto atkarpoje tarp Rąžès upelio ir Palangos tilto, nors kopagūbryje ir buvo akumuliuota apie $0,7 \mathrm{~m}^{3} / \mathrm{m}$, tačiau iš paplūdimio buvo išplauta $21,2 \mathrm{~m}^{3} / \mathrm{m}$ smèlio. Todèl šiame ruože bendras kranto sąnašų biudžetas po 


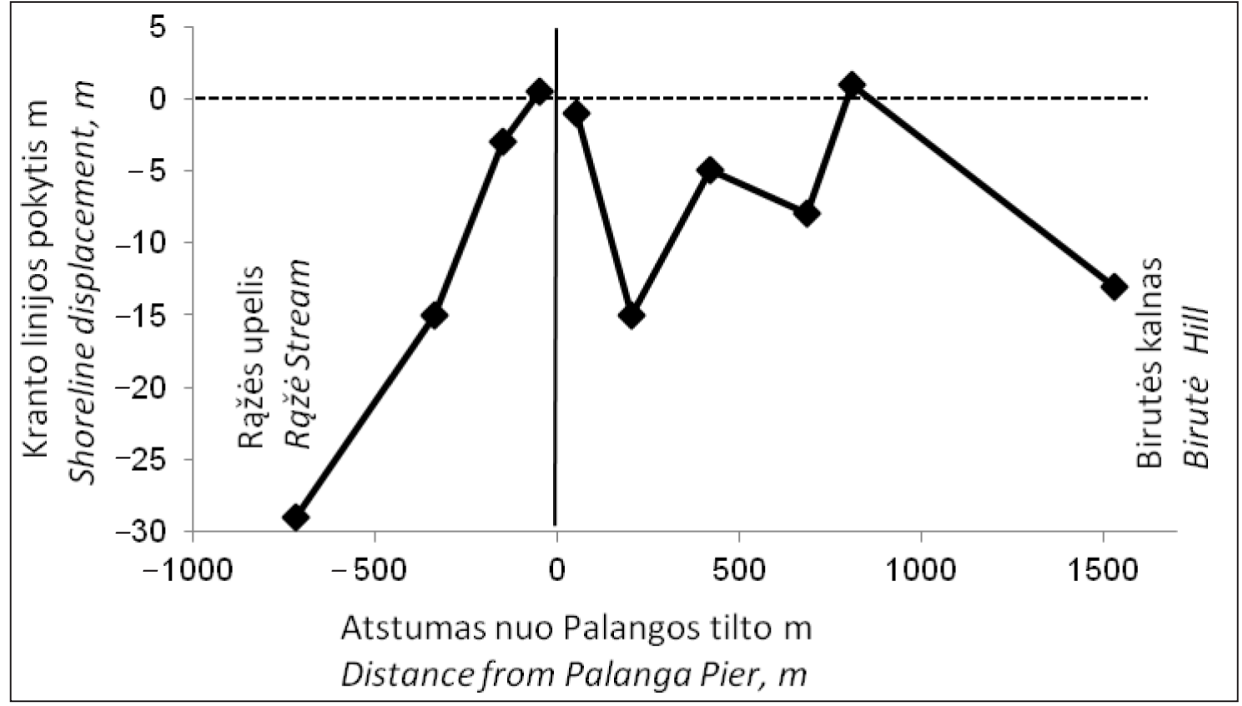

8 pav. Kranto linijos padèties pokytis po štormo kranto ruože tarp Rąžès upelio ir Birutès kalno Fig. 8. Displacement of shoreline position between the Raže Stream and Birute Hill after the storm štormo buvo neigiamas - išplauto smèlio kiekis sudare $13900 \mathrm{~m}^{3}$ (arba 20,5 m³ $/ \mathrm{m}$ ). Kranto ruože tarp Palangos tilto ir Birutès kalno, nors kopagūbryje irgi buvo akumuliuota apie $1,2 \mathrm{~m}^{3} / \mathrm{m}$ smèlio, iš paplūdimio buvo išplauta apie $13,1 \mathrm{~m}^{3} / \mathrm{m}$. Todèl ir šiame ruože bendras kranto sąnašų biudžetas po štormo buvo neigiamas - išplauto smèlio kiekis sudare apie $20210 \mathrm{~m}^{3}$ (arba 11,9 m $\left.\mathrm{m}^{3} / \mathrm{m}\right)$. Palyginus šiuos nuostolius su 2011-2012 m. čia išpilto smèlio kiekiu, apskaičiuota, kad šiaurinejje dalyje (Rąžès upelis - Palangos tiltas) krantas neteko vidutiniškai tik $11 \%$ viso čia išpilto smèlio kiekio, o pietinèje dalyje (Palangos tiltas - Birutès kalnas) - tik 6,7 \%. Tai santykinai nedidelis „maitinamo" paplūdimio išpilto smèlio kiekio praradimas, atsižvelgiant ị vyravusias ekstremalias hidrometeorologines sąlygas štormo metu.
Likusi žemyno kranto dalis per pastaruosius 16 metų sugeba išlaikyti savo pusiausvyros būklę, t. y. esant tokiam štormų bei uraganų pasikartojamumui (stebimam per pastaruosius 50 metų) krantas spejja atstatyti per štormus bei uraganus prarastus smèlio kiekius, o kai kur net vyrauja ir akumuliaciniai procesai. Ryškiausias pavyzdys - kranto atkarpa piečiau Šventosios upès. Šioje vietoje krantas ramių orų laikotarpiu pasipildo didesnemis smèlio atsargomis nei praranda praūžus stipriam štormui (10 pav.).

Lietuvai priklausančios Kuršių nerijos dalies kranto būklè kol kas tik gerèja. Čia nepaisant siaučiančių štormų nuplauti smèlio kiekiai gana greitai vèl gražinami ị krantą. Išimtis būtų tik apie $150 \mathrm{~m}$ ilgio kranto atkarpa Kopgalyje (prie pietinio Klaipédos uosto molo), šiauriau Pervalkos, ir kelios

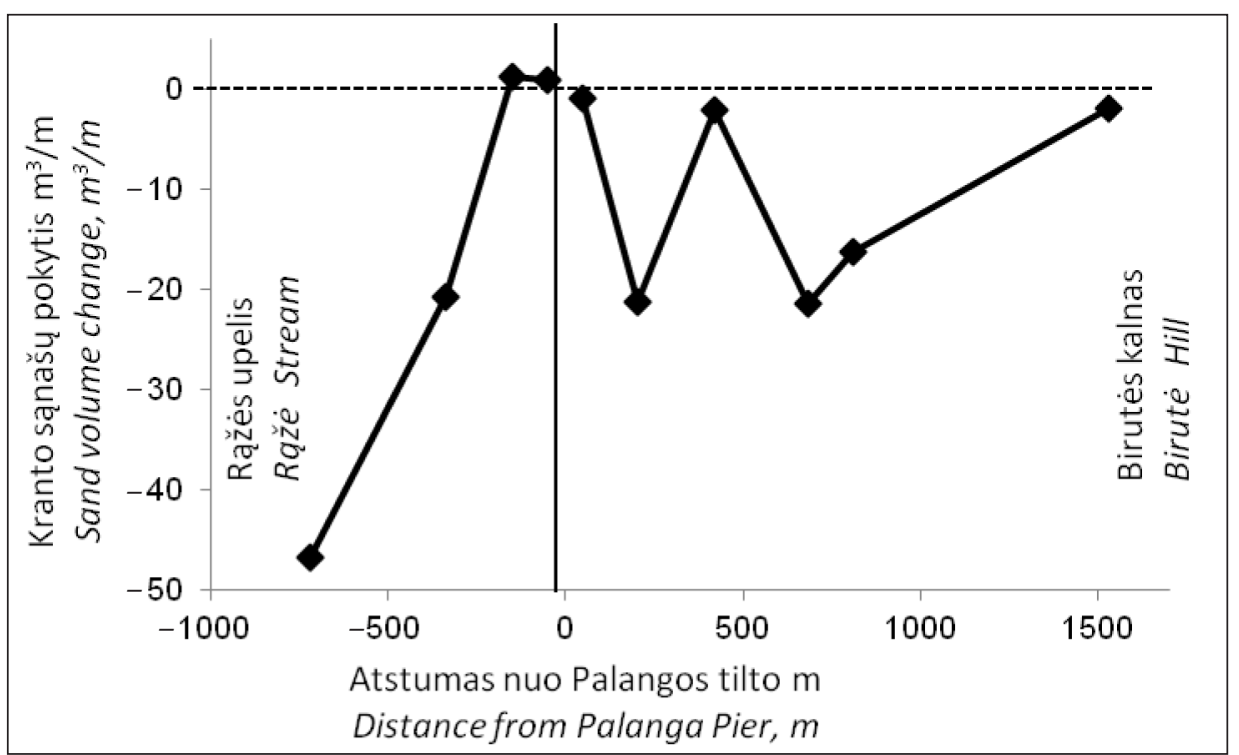

9 pav. Kranto sąnašų kiekio pokytis po štormo kranto ruože tarp Rąžès upelio ir Birutès kalno

Fig. 9. Changes of sand volume between the Rązè Stream and Birute Hill after the storm 


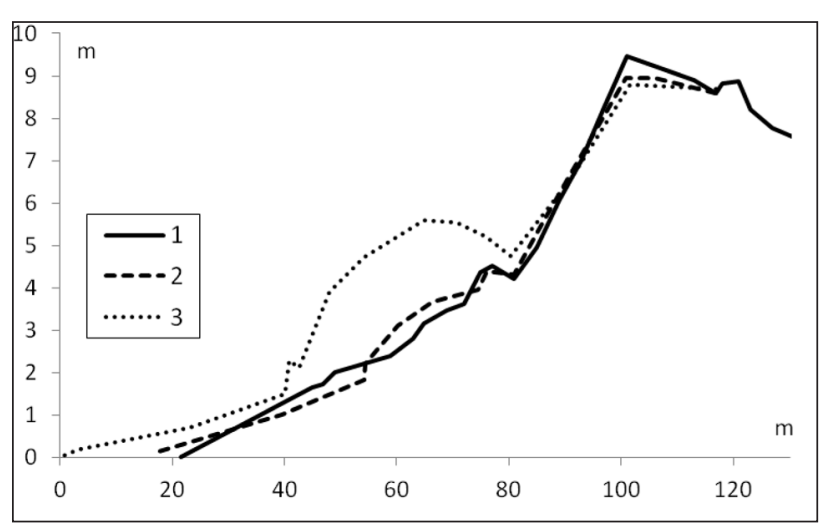

10 pav. Kranto profilis piečiau Šventosios upès po uraganų „Anatolijus“ (1), „Ervinas“ (2) ir štormo „Feliksas“ (3) Fig. 10. Cross-shore profile southward to the Šventoji River after hurricanes Anatolij (1), Ervin (2), and storm Felix (3)

trumpos atkarpèlès ties nedideliais kranto ịlinkiais šiauriau Preilos, piečiau Nidos ir kitur, nesudarančios ilgesnių išplaunamo kranto ruožų. Pažymètina, kad kranto atkarpos šiauriausioje Smiltynès dalyje ardą, kaip ir piečiausioje I-os Melnragès dalyje, lemia uosto molų ir gamtinių veiksnių sąveika (Žilinskas, 1998), o šiauriau Pervalkos nedidelè kranto arda vyksta natūraliai (11 pav.). Čia krantas pastaruosius metus jau nebespeja atstatyti prarasto smèlio per ramių orų laikotarpius.

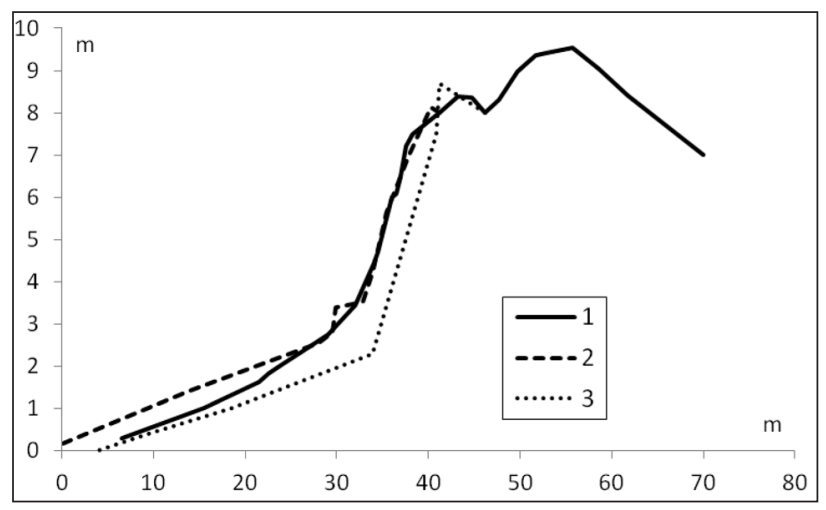

11 pav. Kranto profilis šiauriau Pervalkos po uraganu „Anatolijus“ (1), „Ervinas“ (2) ir štormo „Feliksas“ (3)

Fig. 11. Cross-shore profile northward to Pervalka after hurricanes Anatolij (1), Ervin (2), and storm Felix (3)

Likusioje Kuršių nerijos kranto dalyje vyrauja akumuliacijos procesai. Ryškiausias pavyzdys - Smiltynès-Alksnynès kranto atkarpa, kur ramių orų laikotarpiu smèlio krante susikaupia daugiau nei jo nuplauna štormai ar uraganai (12 pav.).

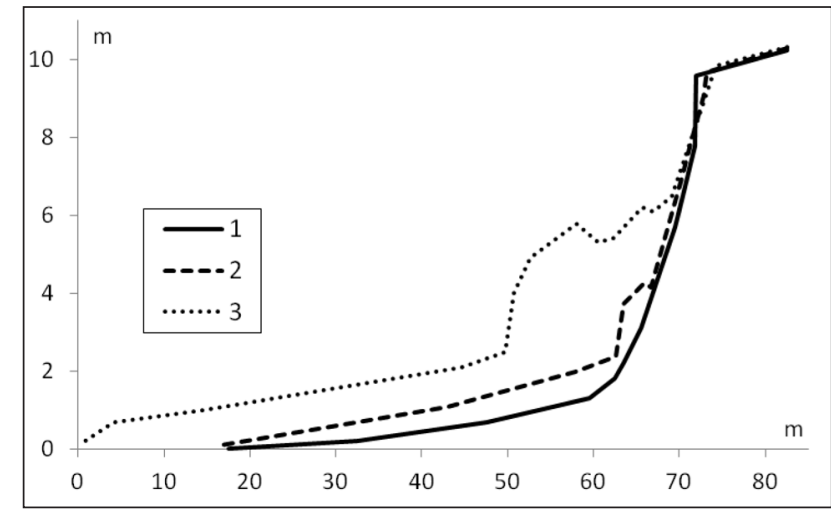

12 pav. Kranto profilis ties Smiltyne po uraganu "Anatolijus“ (1), „Ervinas“ (2) ir štormo „Feliksas“ (3)

Fig. 12. Cross-shore profile near Smiltyne after hurricanes Anatolij (1), Ervin (2), and storm Felix (3)

\section{APIBENDRINIMAS}

Apibendrinant „Felikso“ padarinius Lietuvos jūriniam krantui pažymètina, kad nors šio štormo metu vejo greitis ir nepasieke uraganinio stiprumo (užfiksuotas didžiausias vejo greitis $32,5 \mathrm{~m} / \mathrm{s}$ ), tačiau štormas padarè santykinai nemažų nuostolių. Per štormą Lietuvos jūrinis krantas prarado apie $0,76 \mathrm{mln} . \mathrm{m}^{3}$ sąnašų: $0,39 \mathrm{mln} . \mathrm{m}^{3}$ iš žemyno kranto ir $0,37 \mathrm{~m}^{3} \mathrm{mln}$. iš Kuršių nerijos kranto. Per pastaruosius 50 metų daugiau sąnašų iš viso kranto buvo prarasta tik per 1967 ir $1999 \mathrm{~m}$. uraganus (atitinkamai 1,44 mln. $\mathrm{m}^{3}$; arba 1,9 karto ir 3,94 mln. $\mathrm{m}^{3}$; arba 5,2 karto daugiau). Itakos turèjo jau minèti audringi $2014 \mathrm{~m}$. gruodžio pabaigos ir $2015 \mathrm{~m}$. sausio pradžios orai.

Apžvelgus Lietuvos jūrinio kranto skirtingu ruožų sąnašų pokyčius per štormą „Feliksas“, galima konstatuoti, kad kaip ir visų štormų metu, taip ir per ši, vyko sąnašų perskirstymas tiek išilgai, tiek skersai kranto zonos. Nors didžiojoje kranto dalyje buvo užfiksuoti kranto ardos procesai, tačiau, pavyzdžiui, tarp I-os ir II-os Melnragès, ties Juodkrante, piečiau Preilos, centrineje Nidos dalyje ir kai kur kitur sąnašų krante net pagausèjo.

Vertinant visą krantą nustatyta, kad didžiąją nuoplovos dali (631 $000 \mathrm{~m}^{3}$; arba net $80 \%$ ) sudare paplūdimio sąnašos, o kopagūbris nukentèjo sąlyginai nedaug (127 $000 \mathrm{~m}^{3}$; arba tik $\left.20 \%\right)$. Pažymètina, kad nepaisant santykinai pakankamai didelio tiek žemyno, tiek ir Kuršių nerijos krantų nuardymo per štormą, esant palankioms hidrometeorologinèms sąlygoms ir pakankamai kranto priežiūrai, 
per ateinančius keletą metų kai kuriuose žemyno kranto ruožuose ir beveik visoje Kuršių nerijoje krantas gali pasiekti prieš ši štormą buvusią būklę, t. y. atstatyti savo prarastas smèlio atsargas.

\section{PADE்KA}

Tyrimą iš dalies rèmé Lietuvos mokslo taryba (projektas MIP-039/2014).

Gauta 20150302

Priimta 20150312

\section{LITERATŪRA}

1. Castelle B., Turner I. L., Ruessink B. G., Tomlinson R. B. 2007. Impact of storms on beach erosion: Broadbeach (Gold Coast, Australia). Journal of Coastal Research. SI 50: 534-539.

2. Corbella S., Stretch D. 2012. Predicting coastal erosion trends using non-stationary statistics and process-based models. Coastal Engineering. 70: 40-49.

3. Eberhards G., Lapinskis J., Saltupe B. 2006. Hurricane Erwin 2005 coastal erosion in Latvia. Baltica. 19(1): 10-19.

4. Eberhards G. 2003. Latvijas jūras krasti. Riga: Latvijas universitate.

5. Gorman L., Morang A., Larson R. 1998. Monitoring the coastal environment; Part IV: Mapping, shoreline changes and bathymetric analysis. Journal of Coastal Research. 14(1): 61-92.

6. Jarmalavičius D., Žilinskas G., Pupienis D. 2012. Impact of Klaipeda port jetties reconstruction on adjacent sea coast dynamics. Journal of Environmental Engineering and Landscape Management. 20(3): 240-247.

7. Keijsers J. G. S., Poortinga A., Riksen M. J. P. M., Maroulis J. 2014. Spatio-temporal variability in accretion and erosion of coastal foredunes in the Netherlands: regional climate and local topography. PLoS ONE. 9(3): e91115. doi:10.1371/journal. pone.0091115.

8. Kirlys V. 1990. Uraganiniu (ekstreminiu) štormu poveikis sekliam smèlingam pietrytinès Baltijos jūros dalies krantui. Baltijos jūros krantų dinamikos ir paleografijos klausimai. 1(1): 83-96.

9. Korobova I. J. 1969. Iskliuchitelny shtorm 17-18 oktiebrya 1967 g. i iego vliyaniie na riezhym Klaipedskogo podkhodnogo kanala. Okeanologiya. 9(6): 1124-1127.

10. Krapivin V. F., Varotsos C. A., Soldatov V. Y. 2015. New Ecoinformatics Tools in Environmental Science: Applications and Decision. London: Springet International Publishing.

11. Kriaučiūnienė J., Žilinskas G., Pupienis D., Jarmalavičius D., Gailiušis B. 2013. Impact of Šventoji port jetties on coastal dynamics of the Baltic Sea. Journal of Environmental Engineering and Landscape Management. 21(2): 114-122.

12. Pupienis D., Jarmalavičius D., Žilinskas G., Fedorovič J. 2014. Beach nourishment experiment in Palanga, Lithuania. Journal of Coastal Research. SI 70: 490-495.

13. Pupienis D., Jonuškaitė S., Jarmalavičius D., Žilinskas G. 2013. Klaipeda port jetties impact on the Baltic Sea shoreline dynamics, Lithuania. Journal of Coastal Research. SI 65: 2167-2172.

14. Shuiskiy J. D. 1969. O vozdeistvii silnykh shtormov na peschanyye berega vostochnoy Baltiki. Okeanologiya. 9(3): 475-478.

15. Šimoliūnas J. 1933. Šventosios uostas. Kaunas.

16. Žaromskis R. 1982. Uraganinių audrų poveikis Lietuvos pajūriui. Geografijos metraštis. 20: 89-97.

17. Žilinskas G., Janukonis Z., Lazauskas A. 1994. Ekstremalaus 1993 m. štormo padarinių Palangos rekreacineje kranto zonoje ịvertinimas. Geografija. 30: $40-44$.

18. Žilinskas G., Jarmalavičius D., Kulvičienė G. 2000. Uragano „Anatolijus“ padariniai Lietuvos jūriniame krante. Geografijos metraštis. 33: 191-206.

19. Žilinskas G., Jarmalavičius D., Pupienis D. 2005. Uragano „Ervinas“ padarinių Lietuvos jūriniame krante ivertinimas. Geografijos metraštis. 38(1): 47-63.

20. Žilinskas G., Pupienis D., Jarmalavičius D., 2010. Possibilities of regeneration of Palanga coastal zone. Journal of Environmental and Landscape Management. 18(2): 95-101.

21. Žilinskas G. 1998. Kranto linijos dinamikos ypatumai Klaipedos uosto poveikio zonoje. Geografijos metraštis. 31: 99-109. 
Darius Jarmalavičius, Gintautas Žilinskas, Donatas Pupienis

\section{ASSESSMENT OF THE EFFECTS OF STRONG STORM FELIX ON THE LITHUANIAN MARINE COAST}

\section{Sum mary}

The intensity of hydro-lithodynamic processes in the coastal zone during storms reaches its maximum. For this reason in a relatively short time span (from a few hours to a few days) the morphological changes of the coastal zone by many times exceed the range of not only annual but also long-term changes. Unfortunately, instrumental measurements of hydro-lithodynamic processes in the coastal zone under extreme hydrometeorological conditions during storms are not carried out with an exeption of water level and wind speed and direction recordings. For this reason the judgements about the intensity of these processes are made on the basis of assessments of the character and range of hurricane effects.

Investigations of the effects of the storm Felix, which blew over on January 11, 2015, were carried out right af- ter its slackening - on January 22-27. The instrumental measurements (levelling of the cross-sections of coastal profiles) were made in measuring stations distributed over the whole coastal area of Lithuania (50 stations in the Curonian and 48 in the mainland coast). One measuring station represented an approximately $0.9 \mathrm{~km}$ long coastal sector.

Analysis of the dynamic of the Lithuanian marine coast during the storm Felix revealed that during all stronger storms the sediments were redistributed along and across the coastal zone. Erosion of some coastal sectors during extreme storms creates favourable conditions for preservation of stability and even for sand accumulation in the neighbouring sectors. Intensive erosion in the mainland coast was observed near the Lithuanian-Latvian border and near Melnragè I. The total sand volume washed out from the mainland coast reaches $366000 \mathrm{~m}^{3}$ $\left(9.7 \mathrm{~m}^{3} / \mathrm{m}\right)$ including $316000 \mathrm{~m}^{3}\left(8.4 \mathrm{~m}^{3} / \mathrm{m}\right)$ from the beach and $50000 \mathrm{~m}^{3}\left(1.3 \mathrm{~m}^{3} / \mathrm{m}\right)$ from the foredune. The Curonian Spit coast lost $392000 \mathrm{~m}^{3}\left(7.7 \mathrm{~m}^{3} / \mathrm{m}\right)$ sand including $315000 \mathrm{~m}^{3}\left(6.2 \mathrm{~m}^{3} / \mathrm{m}\right)$ from the beach and $77000 \mathrm{~m}^{3}\left(1.5 \mathrm{~m}^{3} / \mathrm{m}\right)$ from the foredune.

Key words: storm Felix, shore, beach, foredune erosion, Baltic Sea 